\title{
Prediction of High Temperature Behavior of Geopolymer from Solid Wastes Using Gibbs Energy Minimization Approach
}

\author{
Aprilina Purbasari ${ }^{1, *}$, Tjokorde Walmiki Samadhi ${ }^{2}$ and Yazid Bindar $^{2}$ \\ ${ }^{1}$ Department of Chemical Engineering, Faculty of Engineering, Diponegoro University, Jl. Prof. Soedarto, Semarang 50275, Indonesia \\ ${ }^{2}$ Department of Chemical Engineering, Faculty of Industrial Technology, Bandung Institute of Technology, Jl. Ganesha No. 10, \\ Bandung 40132, Indonesia
}

Received 9 December 2019; Accepted 24 February 2020

\begin{abstract}
Geopolymer, alumino-silicate inorganic polymer, has the potential to substitute Portland cement because of its lower energy consumption and $\mathrm{CO}_{2}$ emissions, as well as its raw material can use solid wastes such as fly ash, slag, and biomass ash. Geopolymer as Portland cement substitute in addition to having good mechanical strength must also have resistance to high temperature exposure which can be predicted from its solidus and liquidus temperatures. Solidus temperature indicates the occurrence of melting when the solid is heated, while the liquidus temperature indicates the occurrence of precipitation when the liquid is cooled. Thus geopolymer having high solidus and liquidus temperatures demonstrates its resistance to high temperature exposure. In this paper, composition effect of raw material mixture (fly ash, slag, and biomass ash) on the solidus and liquidus temperatures of geopolymer had been studied using experimental design of 3-components mixture. Solidus and liquidus temperatures of geopolymer in each mixture composition were determined using Gibbs energy minimization approach by FactSage 6.3 software, while the effect of mixture composition on solidus and liquidus temperatures was determined statistically by Minitab 17 software. Phase changes were observed in temperature range of $100-2500{ }^{\circ} \mathrm{C}$ and simulation results showed that geopolymers had solidus temperatures of $500-972.4{ }^{\circ} \mathrm{C}$ and liquidus temperatures of $2146.1-2491.5^{\circ} \mathrm{C}$. Solidus and liquidus temperatures obtained in each simulation were treated statistically resulting linear regression model for solidus temperature and special cubic regression model for liquidus temperature. Fly ash component had the highest positive effect on both solidus and liquidus temperatures of geopolymer compared to slag and biomass ash components. Therefore, geopolymer product having high solidus and liquidus temperatures was obtained with composition of raw material mixture dominated by fly ash.
\end{abstract}

Keywords: experimental design of 3-components mixture; geopolymer; Gibbs energy minimization approach; liquidus temperature; solid waste; solidus temperature

\section{Introduction}

Portland cement is a building material that has been widely used and its use tends to increase. World cement production in 2006 is about 2540 million tons and increase to about 4080 million tons in 2013 [1]. Cement production, which requires temperature of $1400{ }^{\circ} \mathrm{C}$, is an energy intensive process. The dry process consumes energy about $4.60 \mathrm{GJ}$ per ton of clinker, while for wet process the required energy can reach 5.85-6.28 GJ per ton of clinker [2]. The $\mathrm{CO}_{2}$ emissions generated in the production of cement around 0.9 ton $\mathrm{CO}_{2}$ per ton of cement and $\mathrm{CO}_{2}$ emissions of cement industry has contributed approximately $5 \%$ of global $\mathrm{CO}_{2}$ emissions [3].

Several alternatives to Portland cement with lower energy consumption and $\mathrm{CO}_{2}$ emissions are calcium sulphoaluminate cement, magnesium-based cement, and geopolymer. Geopolymer is more potential to be developed as a Portland cement substitute because geopolymer production takes place at low temperatures (below $100{ }^{\circ} \mathrm{C}$ ) and can use waste materials such as fly ash, biomass ash, and slag [4]. Geopolymerisation process involves complex reactions between materials containing alumino-silicate oxide with alkali hydroxide/silicate at temperature below $100{ }^{\circ} \mathrm{C}$. This

\footnotetext{
*E-mail address: aprilina.purbasari@che.undip.acid

ISSN: 1791-2377 @ 2020 School of Science, IHU. All rights reserved.

doi:10.25103/iestr. 132.22
}

produces $\mathrm{Si}-\mathrm{O}-\mathrm{Al}$ polymeric bond with the empirical formula of $\mathrm{M}_{\mathrm{n}}\left(-\left(\mathrm{SiO}_{2}\right)_{\mathrm{z}}-\mathrm{AlO}_{2}\right)_{\mathrm{n}} \cdot \mathrm{wH}_{2} \mathrm{O}$, where: $\mathrm{M}=$ cation $\mathrm{Na}^{+} / \mathrm{K}^{+} ; \mathrm{z}=$ $1,2,3 ; \mathrm{n}=$ degree of polycondensation. Reaction of geopolimerisation is as follows [5]:

$$
\begin{aligned}
& \left(\mathrm{Si}_{2} \mathrm{O}_{5}, \mathrm{Al}_{2} \mathrm{O}_{2}\right) \mathrm{n}+3 \mathrm{nH}_{2} \mathrm{O} \stackrel{\mathrm{NaOH} / \mathrm{KOH}}{\longrightarrow} \mathrm{n}(\mathrm{OH})_{3}-\mathrm{Si}-\mathrm{O}-\mathrm{Al}^{-}-(\mathrm{OH})_{3}(1) \\
& \text { (Si-Al material) Orthosialate } \\
& \mathrm{n}(\mathrm{OH})_{3}-\mathrm{Si}-\mathrm{O}-\mathrm{Al}^{-}-(\mathrm{OH})_{3} \stackrel{\mathrm{NaOH} / \mathrm{KOH}}{\longrightarrow}(\mathrm{Na}, \mathrm{K})\left(-\mathrm{Si}-\mathrm{O}-\mathrm{Al}^{-}-\mathrm{O}-\right) \mathrm{n} \\
& +3 \mathrm{n} \mathrm{H}_{2} \mathrm{O} \\
& \mathrm{O} \quad \mathrm{O} \\
& \text { Orthosialate } \quad(\mathrm{Na}, \mathrm{K}) \text {-poly(sialate) }
\end{aligned}
$$

Three-dimensional structure of geopolymer products are amorphous to semi-crystalline and can be poly(sialate)/(-SiO-Al-O-) for $\mathrm{Si}: \mathrm{Al}=1: 1$, poly(sialate-siloxo)/(-Si-O-Al-O$\mathrm{Si}-\mathrm{O}-)$ for $\mathrm{Si}: \mathrm{Al}=2: 1$, or poly(sialate-disiloxo $) /(-\mathrm{Si}-\mathrm{O}-\mathrm{Al}-\mathrm{O}-$ $\mathrm{Si}-\mathrm{O}-\mathrm{Si}-\mathrm{O}-)$ for $\mathrm{Si}: \mathrm{Al}=3: 1$ [5].

Sources of alumino-silicate material are natural mineral (for example: kaolin), waste from combustion of coal (fly ash) and biomass, and waste from steel industry (slag). Fly ash from coal combustion and slag has been used extensively in the cement production. In addition to improving the cement 
Aprilina Purbasari, Tjokorde Walmiki Samadhi and Yazid Bindar/

Journal of Engineering Science and Technology Review 13 (2) (2020) 185 - 190

quality, fly ash or slag usage would reduce the amount of clinker in cement so that the energy for clinker production could also be reduced [2]. Utilization of waste products of combustion, i.e. fly ash and biomass ash, and slag for geopolymer as a Portland cement substitute is an attempt to reduce the burden on the environment and can also contribute to the reduction of $\mathrm{CO}_{2}$ emissions.

Geopolymer as a Portland cement substitute in addition to having good mechanical strength must also have resistance to high temperature exposure. Geopolymer has shown better resistance to fire than Portland cement [4]. Exposure of Portland cement-based mortars and concretes to temperature above $300{ }^{\circ} \mathrm{C}$ can decompose $\mathrm{Ca}(\mathrm{OH})_{2}$ into $\mathrm{CaO}$ and $\mathrm{H}_{2} \mathrm{O}$ which causes mortar shrinkage [6]. Furthermore $\mathrm{CaO}$ may react with water vapour in air to form $\mathrm{Ca}(\mathrm{OH})_{2}$ having greater volume than $\mathrm{CaO}$ so that mortar will crack resulting in mortar damage.

To determine the resistance of geopolymer to high temperature exposure, it can be predicted from its solidus and liquidus temperatures. Solidus temperature indicates the occurrence of melting when the solid is heated, while the liquidus temperature indicates the occurrence of precipitation when the liquid is cooled [7]. Thus geopolymer having high solidus and liquidus temperatures demonstrates its resistance to high temperature exposure.

This paper studies the composition effect of raw material mixture (fly ash, slag, and biomass ash) on high temperature behavior of geopolymer product, i.e. solidus and liquidus temperatures. Determination of solidus and liquidus temperatures was conducted using Gibbs energy minimization approach with FactSage 6.3 software, whereas determination of the composition effect of raw material mixture statistically was conducted with Minitab 17 software. Several studies related to the use of FactSage software have been carried out such as determination of phase compositions in manganese ores calcination [8], determination of liquidus temperature in Portland clinker [9], determination of liquidus temperature in copper smelting [10], and prediction of ash behaviour and ash fusion temperature [11].

\section{Experimental}

Determination of solidus and liquidus temperatures by FactSage software uses phase equilibrium calculation with minimization of the Gibbs energy change.

$\Delta G<0$

$G-\sum n_{m} G_{m}<0$

$G=\sum n_{m} G_{m}=$ minimum

where: $\Delta G=$ Gibbs energy change, $n_{m}=$ mole numbers of component $m$, and $G_{m}=$ Gibbs energy of component $m$. One of the models used in FactSage software for oxides, salts, and metal alloys with short-range-ordering is modified quasichemical [12].

The Gibbs energy for solution is:

$G=\sum n_{m} g_{m}^{o}-T \Delta S^{\text {config }}+\sum_{n>m} \sum n_{m n}\left(\frac{\Delta g_{m n}}{2}\right)$

where: $g_{m}^{o}=$ Gibbs energy of pure component $m, T=$ temperature, $\Delta S^{\text {config }}=$ configurational entropy of mixing, $n_{m n}=$ mole numbers of $m-n$ pair, and $\Delta g_{m n}=$ nonconfigurational Gibbs energy change for formation of 2 moles of $m-n$ pair.

For multicomponent solution [13]:

$$
\begin{aligned}
& G=\left(n_{11} g_{11}^{o}+n_{12} g_{12}^{o}+n_{22} g_{22}^{o}+n_{13} g_{13}^{o}+\cdots\right)- \\
& T \Delta S^{\text {config }}+\sum_{n>m} \sum\left(\frac{n_{m n}}{2}\right)\left(\Delta g_{m n}-\Delta g_{m n)}^{o}\right.
\end{aligned}
$$

with:

$$
\begin{aligned}
& \Delta S^{\text {config }}=-R \sum_{m} \ln X_{m}-R\left(\sum n_{m m} \ln \left(X_{m m} / Y_{m}^{2}\right)+\right. \\
& \left.\sum_{m>n} \sum n_{m n} \ln \left(X_{m n} / 2 Y_{m} Y_{n}\right)\right) \\
& \Delta g_{m n}=\Delta g_{m n}^{o}+\sum_{(i+j) \geq 1} g_{m n}^{i j} X_{m m}^{i} X_{n n}^{j}
\end{aligned}
$$

where: $R=$ universal gas constant, $X_{m}=$ mole fraction of component $m, X_{m n}=$ mole fraction of $m-n$ pair, and $Y_{m}=$ coordination-equivalent fraction of component $m$.

Module of calculation used in FactSage software was Equilib with SLAGE solution phase, namely an oxide mixture of $\mathrm{Al}, \mathrm{Ca}, \mathrm{Cu}, \mathrm{Fe}, \mathrm{K}, \mathrm{Mg}, \mathrm{Mn}, \mathrm{Na}, \mathrm{Si}$, Ti with $\mathrm{H}_{2} \mathrm{O} / \mathrm{OH}, \mathrm{Cl}$, $\mathrm{SO}_{4}, \mathrm{PO}_{4}$. Data required to determine solidus and liquidus temperatures were oxide compositions of geopolymer raw material, in this case fly ash, slag, and biomass ash (palm oil fuel ash) as presented in Tab. 1. In each simulation run by FactSage software, it was used 100 grams mixture of fly ash, slag, and biomass ash as alumino-silicate material with certain composition reacted with $5 \mathrm{~N} \mathrm{KOH}$ as alkaline activator with weight ratio of 2:1 to form geopolymer. The composition of raw material (fly ash, slag, biomass ash) used in each simulation was based on experimental design of 3components mixture generated by Minitab software with 10 compositions as shown in Fig. 1. Phase changes of formed geopolymer were observed in temperature range of 100-2500 ${ }^{\circ} \mathrm{C}$.

Table 1. Composition (wt-\%) of fly ash, slag, and biomass ash [14]

\begin{tabular}{l|c|c|c}
\hline \multicolumn{1}{c|}{ Component } & Fly ash & Slag & $\begin{array}{c}\text { Biomass } \\
\text { ash }\end{array}$ \\
\hline $\mathrm{SiO}_{2}$ & 55.30 & 32.68 & 63.49 \\
$\mathrm{Al}_{2} \mathrm{O}_{3}$ & 27.28 & 13.71 & 5.55 \\
$\mathrm{Fe}_{2} \mathrm{O}_{3}$ & 5.15 & 0.76 & 4.19 \\
$\mathrm{CaO}$ & 5.31 & 45.83 & 4.34 \\
$\mathrm{MgO}$ & 1.10 & 3.27 & 3.74 \\
$\mathrm{Na} 2$ & 0.43 & 0.25 & 0.16 \\
$\mathrm{~K}_{2} \mathrm{O}$ & 1.00 & 0.48 & 6.33 \\
$\mathrm{TiO}_{2}$ & 1.82 & 0.73 & 0.33 \\
$\mathrm{MnO}_{\mathrm{P}_{2} \mathrm{O}_{5}}$ & 0.10 & 0.35 & 0.17 \\
$\mathrm{SO}_{3}$ & 1.12 & 0.04 & 3.78 \\
$\mathrm{SrO}_{\mathrm{Cl}}$ & 1.01 & 1.80 & 0.91 \\
$\mathrm{CuO}$ & 0.36 & 0.08 & 0.02 \\
\hline
\end{tabular}

Solidus and liquidus temperatures obtained in each simulation then statistically were treated by Minitab software. Regression model of mixture experiment can be linear, quadratic, full cubic, or special cubic equation [15]. By analysis of variance (ANOVA) the adequate equations for solidus and liquidus temperatures could be determined. These equations could be used to predict solidus and liquidus temperatures of geopolymer with fly ash, slag, and biomass ash as raw material. Furthermore, the composition effect of raw material mixture on solidus and liquidus temperatures could be determined from the equations. 
Aprilina Purbasari, Tjokorde Walmiki Samadhi and Yazid Bindar/

Journal of Engineering Science and Technology Review 13 (2) (2020) 185 - 190

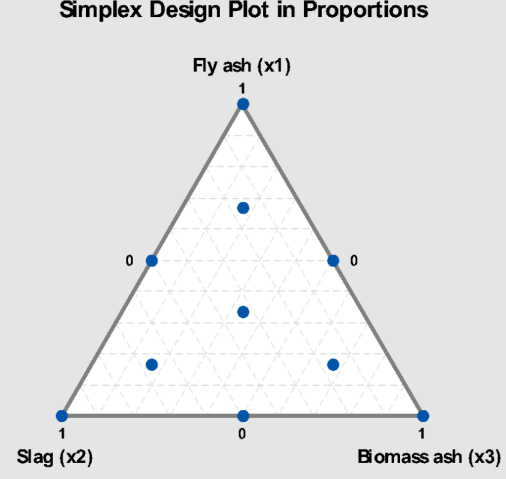

Fig.1. Experimental design of 3-components mixture

\section{Result and Discussion}

\subsection{Solidus and liquidus temperatures of geopolymer}

Solidus and liquidus temperatures of geopolymer resulted by simulation using FactSage software on each mixture composition of raw material are presented in Tab. 2. The range of the solidus temperature of geopolymer is 500-972.4 ${ }^{\circ} \mathrm{C}$, while the liquidus temperature is $2146.1-2491.5{ }^{\circ} \mathrm{C}$. At various temperature ranges geopolymer can undergo dehydration of free water $\left(100-300{ }^{\circ} \mathrm{C}\right)$; dehydroxylation (250-600 $\left.{ }^{\circ} \mathrm{C}\right)$; densification by viscous sintering (550-900 ${ }^{\circ} \mathrm{C}$ ); and crystallization, expansion due to cracking, further densification $\left(>900{ }^{\circ} \mathrm{C}\right)$ [16]. Thus at temperature of 550-900 ${ }^{\circ} \mathrm{C}$ it begins to form liquid. This range is not much different with the solidus temperatures obtained by FactSage (500$972.4^{\circ} \mathrm{C}$ ) where at that temperature molten slag begins to be formed.

Table 2. Solidus and Liquidus temperatures of geopolymer, calculated using Factsage software

\begin{tabular}{|c|c|c|c|c|c|c|}
\hline \multirow[b]{2}{*}{ Mixture No. } & \multicolumn{3}{|c|}{ Component } & \multirow[b]{2}{*}{$\begin{array}{c}\mathrm{K}_{2} \mathrm{O} / \mathrm{Al}_{2} \mathrm{O}_{3} \\
\text { ratio }\end{array}$} & \multicolumn{2}{|c|}{ Responses } \\
\hline & $\begin{array}{c}\text { Fly ash } \\
\left(\mathbf{x}_{1}\right)\end{array}$ & $\begin{array}{l}\text { Slag } \\
\left(\mathbf{x}_{2}\right)\end{array}$ & $\begin{array}{c}\text { Biomass ash } \\
\left(\mathbf{x}_{3}\right)\end{array}$ & & $\begin{array}{l}\mathbf{T}_{\text {Solidus }} \\
\left({ }^{\circ} \mathbf{C}\right)\end{array}$ & $\begin{array}{l}\mathbf{T}_{\text {Liquidus }} \\
\left({ }^{\circ} \mathrm{C}\right)\end{array}$ \\
\hline M1 & 1 & 0 & 0 & 0.79 & 972.4 & 2491.5 \\
\hline M2 & 0 & 1 & 0 & 1.52 & 500 & 2146.1 \\
\hline M3 & 0 & 0 & 1 & 4.91 & 600 & 2124.4 \\
\hline M4 & $1 / 2$ & $1 / 2$ & 0 & 1.03 & 851.1 & 2298.6 \\
\hline M5 & $1 / 2$ & 0 & $1 / 2$ & 1.48 & 700 & 2423.8 \\
\hline M6 & 0 & $1 / 2$ & $1 / 2$ & 2.50 & 700 & 2202.8 \\
\hline M7 & $1 / 3$ & $1 / 3$ & $1 / 3$ & 1.50 & 700 & 2256.8 \\
\hline M8 & $2 / 3$ & $1 / 6$ & $1 / 6$ & 1.04 & 750 & 2391.6 \\
\hline M9 & $1 / 6$ & $2 / 3$ & $1 / 6$ & 1.51 & 500 & 2223.0 \\
\hline M10 & $1 / 6$ & $1 / 6$ & $2 / 3$ & 2.40 & 700 & 2277.3 \\
\hline
\end{tabular}

Mineral phases that occur from FactSage calculation are presented in Tab. 3 on simulation with a mixture of fly ash:slag:biomass ash $=1 / 3: 1 / 3: 1 / 3(\mathrm{M} 7)$. This agrees with the results of XRD (X-Ray Diffraction) analysis to geopolymer exposed to high temperatures [16]. Leucite $\left(\mathrm{KAlSi}_{2} \mathrm{O}_{6}\right)$ is a major phase encountered in geopolymer synthesized with alkaline activator containing potassium at temperature about $1000{ }^{\circ} \mathrm{C}$, while hematite $\left(\mathrm{Fe}_{2} \mathrm{O}_{3}\right)$ at temperature about 1200 ${ }^{\circ} \mathrm{C}$. Garnet $\left(\mathrm{Ca}_{3} \mathrm{Fe}_{2} \mathrm{Si}_{3} \mathrm{O}_{12}\right)$ and wollastonite $\left(\mathrm{CaSiO}_{3}\right)$ will be found in geopolymer with slag as raw material due to high calcium content [17].

Table 3. Equilibrium phases in geopolymer (M7) at temperature of $900-1200{ }^{\circ} \mathrm{C}$, calculated using Factsage software

\begin{tabular}{|c|c|}
\hline $\begin{array}{l}\text { Temperature } \\
\left({ }^{\circ} \mathrm{C}\right)\end{array}$ & Phases \\
\hline 900 & $\begin{array}{l}\text { Leucite }\left(\mathrm{KAlSi}_{2} \mathrm{O}_{6}\right), \\
\left(\mathrm{Ca}_{3} \mathrm{MgSi}_{2} \mathrm{O}_{8}\right), \quad \text { merwinite } \\
\left(\mathrm{Ca}_{3} \mathrm{Fe}_{2} \mathrm{Si}_{3} \mathrm{O}_{12}\right), \quad \mathrm{K}_{2} \mathrm{SO}_{4}, \quad{ }^{\circ} \mathrm{Cu}_{2} \mathrm{O} \text {, } \\
\text { perovskite-a }\left(\mathrm{CaTiO}_{3}\right), \text { hydroxyapatite } \\
\left(\mathrm{Ca}_{5} \mathrm{HO}_{13} \mathrm{P}_{3}\right), \quad \text { wollastonite }\left(\mathrm{CaSiO}_{3}\right), \\
(\mathrm{SrO})\left(\mathrm{TiO}_{2}\right), \mathrm{Mn}_{3} \mathrm{O}_{4}\end{array}$ \\
\hline 1000 & 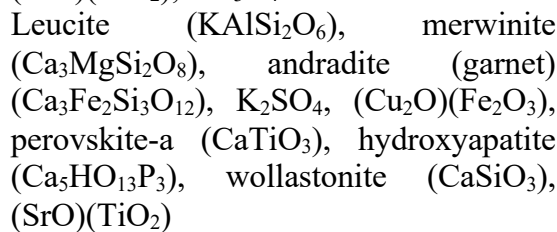 \\
\hline 1100 & 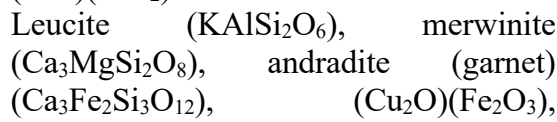 \\
\hline
\end{tabular}

perovskite-a $\left(\mathrm{CaTiO}_{3}\right)$, hydroxyapatite $\left(\mathrm{Ca}_{5} \mathrm{HO}_{13} \mathrm{P}_{3}\right),(\mathrm{SrO})\left(\mathrm{TiO}_{2}\right)$ Leucite $\left(\mathrm{KAlSi}_{2} \mathrm{O}_{6}\right), \mathrm{Ca}_{3}\left(\mathrm{PO}_{4}\right)_{2}$, hematite $\left(\mathrm{Fe}_{2} \mathrm{O}_{3}\right)$, akermanite $\left(\mathrm{Ca}_{2} \mathrm{MgSi}_{2} \mathrm{O}_{7}\right)$, $(\mathrm{SrO})\left(\mathrm{TiO}_{2}\right)$

The liquidus temperature which indicates geopolymer in wholly liquid form is obtained above $2000{ }^{\circ} \mathrm{C}$. Mineral formed or start precipitated at liquidus temperature generally is $(\mathrm{SrO})\left(\mathrm{SiO}_{2}\right)$ or $(\mathrm{SrO})_{2}\left(\mathrm{SiO}_{2}\right)$, but for geopolymer with slag composition $=1(\mathrm{M} 2)$, slag:biomass ash $=1 / 2: 1 / 2(\mathrm{M} 6)$, and fly ash:slag:biomass ash $=1 / 6: 2 / 3: 1 / 6$ (M9) mineral formed is $\mathrm{Ca}_{3}\left(\mathrm{PO}_{4}\right)_{2}$. This is possible because of the high content of $\mathrm{CaO}$ in the slag compared to that in the fly ash and in the biomass ash.

Among the raw materials of fly ash, slag, and biomass ash, solidus and liquidus temperatures of geopolymer from fly ash is the highest. This can be explained by observing the oxides content in raw materials. The oxides composition of silica, alumina, alkali oxide, and water forming geopolymer can affect the mechanical strength of geopolymer, as well as the solidus and liquidus temperatures of geopolymer. To obtain strong geopolymer products, ratios of silica, alumina, alkali oxide, and water are in the following ranges: $\mathrm{SiO}_{2} / \mathrm{Al}_{2} \mathrm{O}_{3}=$ 3.0-4.5; $\mathrm{M}_{2} \mathrm{O} / \mathrm{SiO}_{2}=0.2-0.5 ; \quad \mathrm{H}_{2} \mathrm{O} / \mathrm{M}_{2} \mathrm{O}=10-25 ;$ and $\mathrm{M}_{2} \mathrm{O} / \mathrm{Al}_{2} \mathrm{O}_{3}=0.6-1.6$ [18]. Result of research in [19] showed that the ratio of alkali $\left(\mathrm{K}_{2} \mathrm{O}\right)$ on alumina $\left(\mathrm{Al}_{2} \mathrm{O}_{3}\right)$ had the most effect on the mechanical strength of geopolymer and geopolymer with ratio of $\mathrm{K}_{2} \mathrm{O} / \mathrm{Al}_{2} \mathrm{O}_{3}=0.8$ had the highest mechanical strength. In this simulation, ratio of $\mathrm{K}_{2} \mathrm{O} / \mathrm{Al}_{2} \mathrm{O}_{3}$ in the fly ash is 0.79 or close to 0.8 , while for slag and biomass ash 1.52 and 4.91 , respectively, or greater than 0.8 , likewise 
Aprilina Purbasari, Tjokorde Walmiki Samadhi and Yazid Bindar/

Journal of Engineering Science and Technology Review 13 (2) (2020) 185 - 190

ratio of $\mathrm{K}_{2} \mathrm{O} / \mathrm{Al}_{2} \mathrm{O}_{3}$ in all mixture of fly ash-slag-biomass ash are greater than 0.8 (Tab. 2). The greater the ratio of $\mathrm{K}_{2} \mathrm{O} / \mathrm{Al}_{2} \mathrm{O}_{3}$ or more $\mathrm{K}_{2} \mathrm{O}$ in geopolymer, the lower solidus and liquidus temperatures of geopolymer due to the lowest melting point of $\mathrm{K}_{2} \mathrm{O}\left(740{ }^{\circ} \mathrm{C}\right)$ compared to $\mathrm{SiO}_{2}(1600-1725$ $\left.{ }^{\circ} \mathrm{C}\right)$ and $\mathrm{Al}_{2} \mathrm{O}_{3}\left(2072{ }^{\circ} \mathrm{C}\right)$. Thus the ratio of $\mathrm{K}_{2} \mathrm{O} / \mathrm{Al}_{2} \mathrm{O}_{3}$ in addition affects the mechanical strength of geopolymer also solidus and liquidus temperatures of geopolymer.

\subsection{The composition effect of raw material mixture on} solidus and liquidus temperatures of geopolymer
The composition effect of raw material on solidus and liquidus temperatures of geopolymer can be observed from regression models generated by Minitab software. Analysis of variance (ANOVA) for each regression model obtained for the solidus and liquidus temperatures is presented in Tab. 4 and Tab. 5, respectively. The regression model for solidus temperature of geopolymer that has $\mathrm{P}$-value $<0.05$ is linear model with $R^{2}$-value of $69.91 \%$ and $R_{\mathrm{Adj}}^{2}$-value of $61.31 \%$. Meanwhile regression model for liquidus temperature of geopolymer that has P-value $<0.05$ with the highest value of $R^{2}$ and $R_{\text {Adj }}^{2}$ is special cubic.

Table 4. Anova for regression model of geopolymer solidus temperature, calculated using Minitab software

\begin{tabular}{l|c|c|c|c|c|c|c|c|c|c}
\hline \multicolumn{1}{c|}{ Model } & DF & Adj SS & Adj MS & $\begin{array}{c}\text { DF } \\
\text { Error }\end{array}$ & $\begin{array}{c}\text { Adj SS } \\
\text { Error }\end{array}$ & $\begin{array}{c}\text { Adj MS } \\
\text { Error }\end{array}$ & F & P & $\begin{array}{c}\boldsymbol{R}^{2} \\
(\%)\end{array}$ & $\begin{array}{c}\boldsymbol{R}_{\text {Adj }}^{2} \\
(\%)\end{array}$ \\
\hline Linear & 2 & 132439 & 66219.7 & 7 & 57007 & 8143.9 & 8.13 & 0.015 & 69.91 & 61.31 \\
Quadratic & 5 & 154916 & 30983.3 & 4 & 34530 & 8632.6 & 3.59 & 0.120 & 81.77 & 58.99 \\
$\begin{array}{l}\text { Special } \\
\text { cubic }\end{array}$ & 6 & 163274 & 27212.3 & 3 & 26173 & 8724.4 & 3.12 & 0.189 & 86.18 & 58.55 \\
Full cubic & 8 & 182684 & 22835.5 & 1 & 6763 & 6763.2 & 3.38 & 0.399 & 96.43 & 67.87 \\
\hline
\end{tabular}

Table 5. Anova for regression model of geopolymer liquidus temperature, calculated using Minitab software

\begin{tabular}{l|c|c|c|c|c|c|c|c|c|c}
\hline \multicolumn{1}{c|}{ Model } & DF & Adj SS & Adj MS & $\begin{array}{c}\text { DF } \\
\text { Error }\end{array}$ & $\begin{array}{c}\text { Adj SS } \\
\text { Error }\end{array}$ & $\begin{array}{c}\text { Adj MS } \\
\text { Error }\end{array}$ & F & $\begin{array}{c}\boldsymbol{R}^{\mathbf{2}} \\
(\%)\end{array}$ & $\begin{array}{c}\boldsymbol{R}_{\text {Adj }}^{2} \\
(\%)\end{array}$ \\
\hline $\begin{array}{l}\text { Linear } \\
\text { Quadratic }\end{array}$ & 2 & 115420 & 57709.9 & 7 & 14564 & 2080.6 & 27.74 & 0.000 & 88.80 & 85.59 \\
$\begin{array}{l}\text { Special } \\
\text { cubic }\end{array}$ & 6 & 126230.9 & 25246.2 & 4 & 3753.1 & 938.3 & 26.91 & 0.004 & 97.11 & 93.50 \\
Full cubic & 8 & 129435.4 & 21405.9 & 3 & 1548.6 & 516.2 & 41.47 & 0.006 & 98.81 & 96.43 \\
\hline
\end{tabular}

Adequacy checking for each regression model is conducted from normal probability plot and residual versus fitted value as shown in Fig. 2 for linear model of geopolymer solidus temperature and Fig. 3 for special cubic model of geopolymer liquidus temperature. The normal probability plots of residuals in Fig. 2(a) and Fig. (3a) show that residuals are distributed normally. Furthermore, plots of residuals versus fitted value in Fig. 2(b) and Fig. (3b) indicate that residuals do not form a specific pattern. Thus, it can be concluded that each regression model is adequate.
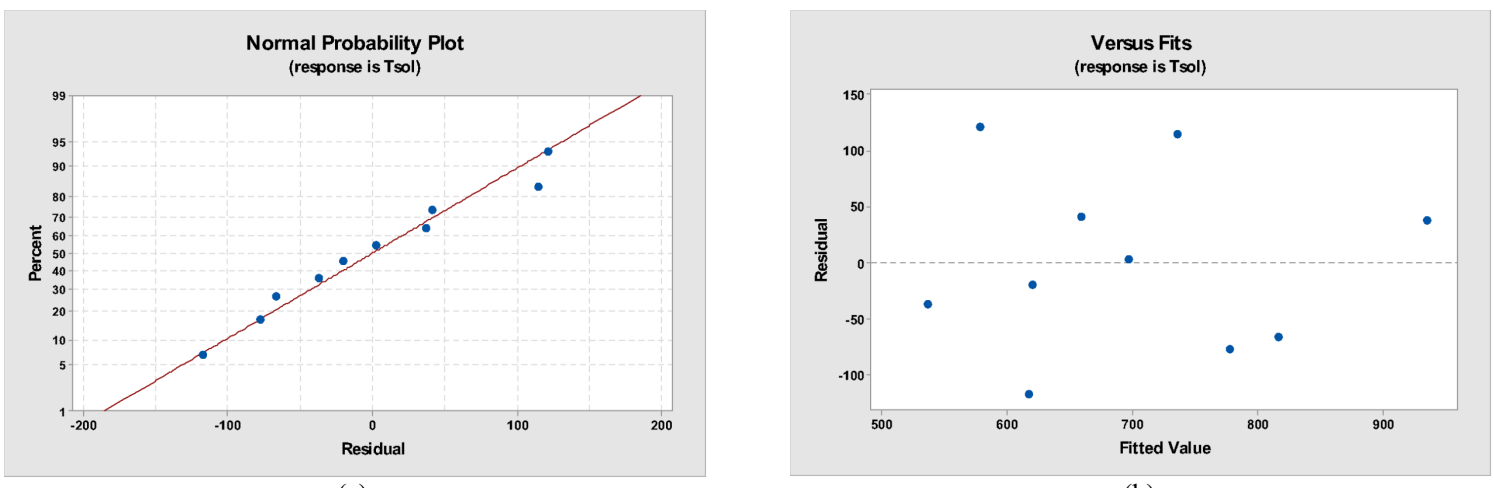

(a)

(b)

Fig. 2. Adequacy checking for linear model of geopolymer solidus temperature: (a) normal probability plot and (b) residual versus fitted value

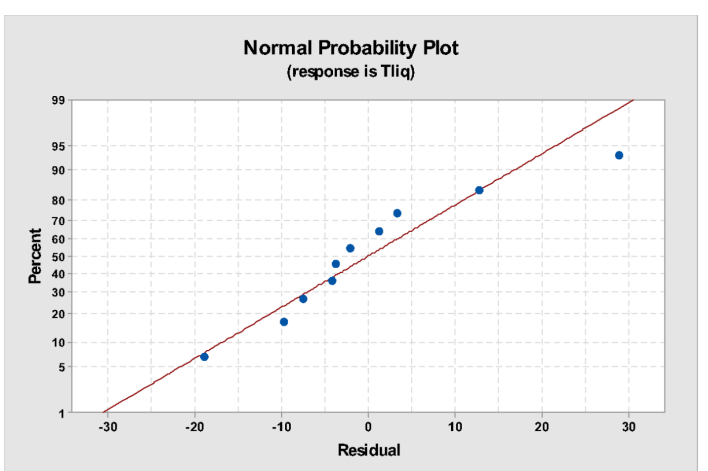

(a)

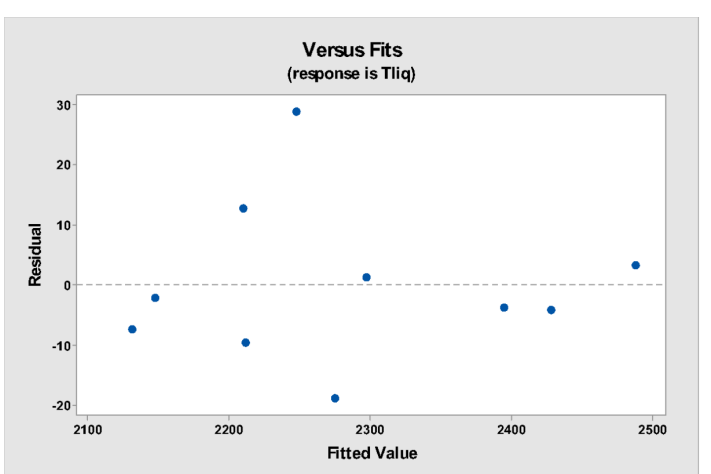

(b)

Fig. 3. Adequacy checking for special cubic model of geopolymer liquidus temperature: (a) normal probability plot and (b) residual versus fitted value 
Equation with linear model to predict the solidus temperature of geopolymer indicated by Eq. 10 and equation with special cubic model to predict the liquidus temperature of geopolymer indicated by Eq. 11 .

$$
\begin{aligned}
& T_{\text {sol }}\left({ }^{o} \mathrm{C}\right)=935.2 x_{1}+536.9 x_{2}+619.9 x_{3} \\
& T_{\text {liq }}\left({ }^{o} \mathrm{C}\right)=2488 x_{1}+2148 x_{2}+2132 x_{3}-83 x_{1} x_{2}+ \\
& 472 x_{1} x_{3}+290 x_{2} x_{3}-1506 x_{1} x_{2} x_{3}
\end{aligned}
$$

where: $T_{\text {sol }}=$ solidus temperature of geopolymer; $T_{\text {liq }}=$ liquidus temperature of geopolymer; $x_{1}=$ fly ash fraction, $x_{2}$ $=$ slag fraction, and $x_{3}=$ biomass ash fraction in the mixture.

At both Eq. 10 and Eq. 11, fly ash fraction $\left(x_{1}\right)$, slag fraction $\left(x_{2}\right)$, and biomass ash fraction $\left(x_{3}\right)$ have positive coefficients or positive effects on solidus and liquidus temperatures of geopolymer. Fly ash component has the highest positive effect compared to slag and biomass ash components. Equation 11 denotes that mixing of fly ashbiomass ash or slag-biomass ash provides positive effect on the liquidus temperature, while mixing of fly ash-slag or mixing of fly ash-slag-biomass ash provides negative effect.

From the contour plots of solidus temperature and liquidus temperature as shown in Fig. 4 and Fig. 5, we can determine the composition of the raw material mixture (fly ash, slag, and biomass ash) that produce geopolymer with expected solidus temperature and liquidus temperature. Higher solidus temperatures in Fig. 4 and higher liquidus temperatures in Fig. 5 are indicated by darker shades, obtained in mixtures with fly ash as the dominant component.

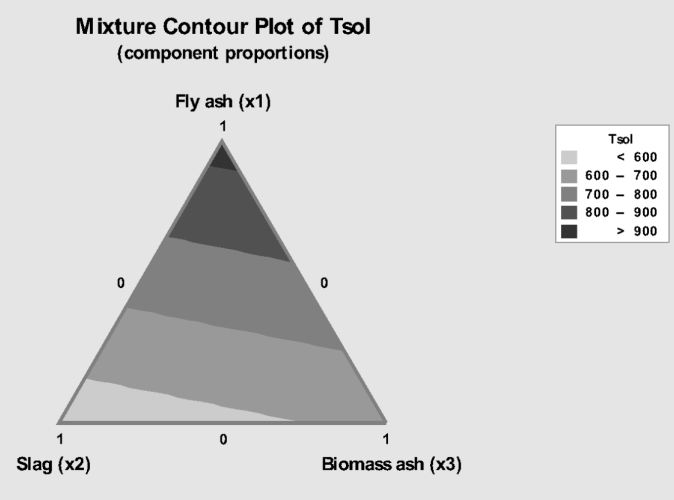

Fig. 4. Contour plot of geopolymer solidus temperature

Geopolymer as a Portland cement substitute is expected having resistance to high temperature exposure or fire. In general, temperature will reach $800{ }^{\circ} \mathrm{C}$ quickly in about 30 minutes during fire. After that, temperature will increase more slowly from $900{ }^{\circ} \mathrm{C}$ to $1200{ }^{\circ} \mathrm{C}$ within 6 hours [20]. Therefore geopolymer having solidus temperatures above $800{ }^{\circ} \mathrm{C}$ indicates having better resistance to fire. From Fig. 4 geopolymer with solidus temperatures above $800{ }^{\circ} \mathrm{C}$ is obtained at mixture of fly ash, slag, and biomass ash with slag composition not more than $\pm 30 \%$ and biomass ash composition not more than $+40 \%$. Thus geopolymer from solid wastes can be predicted to have solidus temperatures above $800{ }^{\circ} \mathrm{C}$ with maximum slag composition of $30 \%$ and maximum biomass ash composition of $40 \%$.

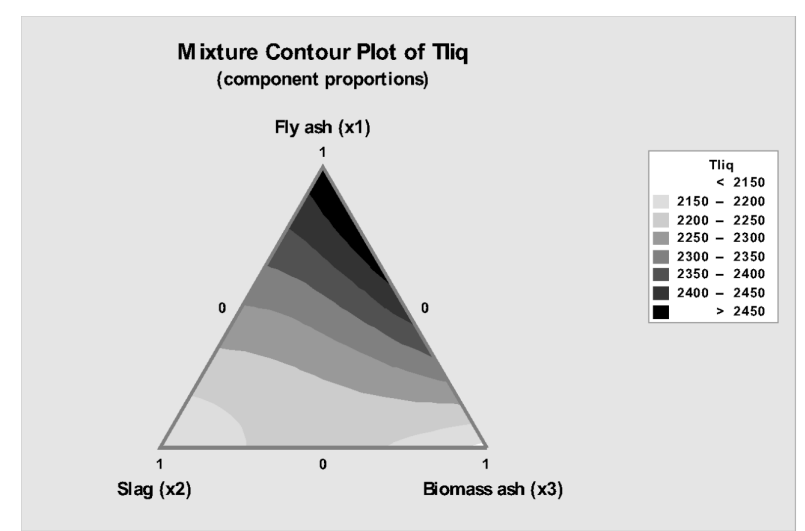

Fig. 5. Contour plot of geopolymer liquidus temperature

\section{Conclusions}

Results of FactSage simulation indicate that geopolymers with raw material mixture of fly ash, slag, and biomass ash have solidus temperatures of $500-972.4{ }^{\circ} \mathrm{C}$ and liquidus temperatures of 2146.1-2491.5 ${ }^{\circ} \mathrm{C}$. Using a mixture experimental design, the effect of raw material composition on solidus and liquidus temperatures of geopolymer can be determined. Fly ash has the highest positive effect on solidus and liquidus temperatures of geopolymer compared to slag and biomass ash so that geopolymer having high solidus and liquidus temperatures can be obtained at raw material mixtures with fly ash as the dominant component.

\section{Acknowledgments}

The authors are grateful to Laboratory of Mineral and Inorganic Material Technology, Bandung Institute of Technology for providing access to software used in this study.

This is an Open Access article distributed under the terms of the Creative Commons Attribution License

\section{References}

[1] Y. Yang, L. Wang, Z. Cao, C. Mou, L. Shen, J. Zhao, and Y. Fang, J. Geogr. Sci., 27(6), p. 711-730 (2017).

[2] A. Naqi and J.G. Jang, Sustainability, 11(2), 537 (2019).

[3] R.M. Andrew, Earth Syst. Sci. Data, 10, p. 195-217 (2018).

[4] J.L. Provis, Cem. Concr. Res., 114, p. 40-48 (2018).

[5] J. Davidovits, J. Ceram. Sci. Technol., 8(3), p. 335-350 (2017).

[6] F.N. Degirmenci, Ceram.-Silik., 62(1), p. 41-49 (2018).

[7] O. Martinik, B. Smetana, J. Dobrovska, A. Kalup, S. Zla, M. Kawulokova, K. Gryc, P. Dostal, L. Drozdova, and B. Baudisova, J. Min. Metall. Sect. B-Metall., 53(3B), p. 391-398 (2017).

[8] B. Sorensen, S. Gaal, E. Ringdalen, M. Tangstad, R. Kononov, and O. Ostrovski, Int. J. Miner. Process., 94, p. 101-110 (2010).
[9] M.-N. de Noirfontaine, S. Tusseau-Nenez, C. Girod-Labianca, and V. Pontikis, J. Mater. Sci., 47(3), p. 1471-1479 (2012).

[10] B. Zhao, P. Hayes, and E. Jak, J. Min. Metall. Sect. B-Metall., 49(2) B, p. 153-159 (2013).

[11] P. Pintana and N. Tippayawong, WSEAS Trans. Environ. Dev., 10, p. 202-210 (2014).

[12] C.W. Bale, P. Chartrand, S.A. Degterov, G. Eriksson, K. Hack, R.B. Mahfoud, J. Melançon, A.D. Pelton, and S. Petersen, Calphad, 26(2), p. 189-228 (2002).

[13] A.D. Pelton and P. Chartrand, Metall. Mater. Trans., 32A, p. $1355-$ 1360 (2001). 
Aprilina Purbasari, Tjokorde Walmiki Samadhi and Yazid Bindar/

\section{Journal of Engineering Science and Technology Review 13 (2) (2020) 185 - 190}

[14] A. Islam, U.J. Alengaram, M.Z. Jumaat, and I.I. Bashar, Mater. Design., 56, p. 833-841 (2014).

[15] D.C. Montgomery, Design and analysis of experiments, 9th ed., John Wiley \& Sons, Inc., New York (2017).

[16] A. van Riessen and W. Rickard in Geopolymers: Structure, processing, properties and industrial applications, J.L. Provis and J.S.J. van Deventer, Eds., Woodhead Publishing Limited and CRC Press LLC, Cambridge p. 315-342 (2009).

[17] G. Kovalchuk and P.V. Krivenko in Geopolymers: Structure, processing, properties and industrial applications, J.L. Provis and

\section{NOMENCLATURE}

$\Delta G$

$\Delta g_{m n}$

Gibbs energy change

$\Delta S^{\text {config }}$ nonconfigurational Gibbs energy change for formation of 2 moles of $m-n$ pair

Adj MS configurational entropy of mixing

Adj SS

DF adjusted mean squares adjusted sum of squares

degrees of freedom

$G_{m} \quad$ Gibbs energy of component $m$

$g_{m}^{o}$

$n_{m}$

$n_{m n}$
Gibbs energy of pure component $m$

mole numbers of component $m$ mole numbers of $m-n$ pair
J.S.J. van Deventer, Eds., Woodhead Publishing Limited and CRC Press LLC, Cambridge p. 227-266 (2009).

[18] J. Davidovits, Geopolymer: Chemistry and applications, 2nd ed., Institut Géopolymère, Saint-Quentin (2008).

[19] Y. Zhang, W. Sun, and Z. Li, J. Cent. South Univ. T., 16, p. 906913 (2009).

[20] ASTM, ASTM E119-18: Standard Test Methods for Fire Tests of Building Construction and Materials, American Society for Testing and Materials, West Conshohocken (2018).

$R \quad$ universal gas constant

$T$ temperature

$T_{\text {liq }} \quad$ liquidus temperature of geopolymer

$T_{\text {sol }} \quad$ solidus temperature of geopolymer

$X_{m} \quad$ mole fraction of component $m$

$X_{m n} \quad$ mole fraction of $m-n$ pair

$Y_{m} \quad$ coordination-equivalent fraction of component $m$

$x_{1} \quad$ fly ash fraction

$x_{2} \quad$ slag fraction

$x_{3} \quad$ biomass ash fraction 